\title{
Taxonomic notes on the genus Ophrys L. (Orchidaceae) in the Crimea and the North Caucasus
}

\author{
A. V. Fateryga ${ }^{1}$, P. G. Efimov ${ }^{2}$, V. V. Fateryga ${ }^{1}$ \\ ${ }^{1}$ T. I. Vyazemsky Karadag Scientific Station - Nature Reserve of RAS, Nauki str., 24, Kurortnoye, Feodosiya, \\ Republic of Crimea, 298188,_Russia.E-mail: fater_84@list.ru \\ ${ }^{2}$ V. L. Komarov Botanical Institute of the Russian Academy of Sciences, Prof. Popov str., 2, St. Petersburg, 197376, Russia. \\ E-mail: efimov81@mail.ru
}

Keywords: distribution, Europe, orchids, Russian flora, synonymy, taxonomy.

Summary. The genus Ophrys L. is one of the most intricate orchid genera. This genus is well-known for its sexual deceptive pollination syndrome, and it is widely accepted that diversification of the genus resulted from adaptations to different pollinators. Despite these strict adaptations, the introgression within Ophrys is quite usual. The unusual pollination system and complex evolution of the genus may be the primary reason for the confused taxonomy and extensive debate over species richness within the genus. Modern estimation of the species richness varies from 9 macrospecies based on the results of molecular analysis to 354 microspecies based on minute morphological differences. The present paper revises the genus Ophrys within the territory of the Crimea and the North Caucasus. Five taxa are recognized: O. apifera Huds., O. mammosa Desf. subsp. mammosa (= O. caucasica subsp. cyclocheila Aver., syn. nov.), O. mammosa subsp. caucasica (Woronow ex Grossh.) Soó, O. oestrifera M. Bieb. (= O. bremifera Steven, syn. nov.; $=O$. oestrifera subsp. abchasica Kümpel, syn. nov.), and $O . \times$ vallis-costae Kümpel $(O$. apifera $\times O$. oestrifera $)$ (=O. $\times$ skopelii nothosubsp. markiana B. Baumann, H. Baumann, R. Lorenz et Ruedi Peter, syn. nov.). A key to the species and subspecies is provided. Ophrys $\times$ vallis-costae is reported for the Crimea for the first time.

\section{Таксономические заметки о роде Ophrys L. (Orchidaceae) в Крыму и на Северном Кавказе}

\author{
А. В. Фатерыга ${ }^{1}$, П. Г. Ефимов², В. В. Фатерыга ${ }^{1}$ \\ ${ }^{1}$ Карадагская научная станция им. Т. И. Вяземского - природный заповедник РАН, ул. Науки, 24, \\ пгт. Курортное, г. Феодосия, Республика Крым, 298188, Россия \\ ${ }^{2}$ Ботанический институт им. В. Л. Комарова РАН, ул. Проф. Попова, 2, г. Санкт-Петербург, 197376, Россия
}

Ключевые слова: Европа, орхидеи, распространение, синонимия, таксономия, флора России.

Аннотация. Род Ophrys L. широко известен благодаря своей системе привлечения опылителей путем полового обмана, и считается, что диверсификация внутри рода является результатом смены адаптаций к различным опылителям. Несмотря на эти узкие адаптации, интрогрессия внутри рода Ophrys достаточно обычна. Следствием особенностей эволюционного процесса является сложная систематика видов рода. Современные оценки видового богатства варьируют от 9 макровидов, выделенных на основе молекулярного анализа, до 354 микровидов, выделяемых на мельчайших морфологических различиях. В настоящей публикации приводится обзор рода Ophrys для территории Крыма и Северного Кавказа. Признается пять таксонов: O. apifera Huds., O. mammosa Desf. subsp. mammosa (= O. caucasica subsp. cyclocheila Aver., syn. nov.), O. mammosa subsp. caucasica (Woronow ex Grossh.) Soó, O. oestrifera M. Bieb. (= O. bremifera Steven, syn. nov.; = O. oestrifera subsp. 
abchasica Kümpel, syn. nov. $)$ и $O . \times$ vallis-costae Kümpel $(O$. apifera $\times O$. oestrifera $)(=O . \times$ skopelii nothosubsp. markiana B. Baumann, H. Baumann, R. Lorenz et Ruedi Peter, syn. nov.). Приводится ключ для определения видов и подвидов. Ophrys $\times$ vallis-costae впервые приводится для Крыма.

\section{Introduction}

Ophrys L., in its current generic boundaries, is one of the most intricate orchid genera. This genus is well-known for its sexual deceptive pollination syndrome. Pollinators of Ophrys spp. are males from several taxonomic groups of wasps and bees (Hymenoptera). The structure and scent of Ophrys flowers mimic females of these insects to attract target males. The latter attempt to copulate with the flowers, which leads to pollination (Kullenberg, 1961; Paulus, 2006; Bradshaw et al., 2010). Such "pseudocopulation" pollination in Ophrys is unique among European orchids. In contrast to a different taxonomically complicated and species-rich genus Epipactis Zinn, in which were most recently described species as locally evolved self-pollinating taxa (Hollingsworth et al., 2006), only one species of Ophrys is self-pollinating. This species is the widespread $O$. apifera Huds.; its autogamy is well-known since the study by R. Brown (1833). All other representatives of the genus are cross-pollinating by "pseudocopulation". It is widely accepted that diversification of the genus was the result of the change of adaptations to different pollinators, changing from wasps of the genera Argogorytes Ashmead (Crabronidae) and Dasyscolia Bradley (Scoliidae) in several basal species to bees of the tribe Eucerini (Apidae) and then to bees of the genus Andrena Fabricus (Andrenidae) and some other genera in the vast majority of other Ophrys species (Paulus, Gack, 1990; Mant et al., 2005; Ayasse et al., 2010; Breitkopf et al., 2015). However, since each species of the genus has more than one pollinator species, and pollinators of some sympatric species may represent the same species, the introgression within Ophrys is not surprising (Stebbins, Ferlan, 1956; Soliva, Widmer, 2003; Paulus, 2007; Vereecken et al., 2011).

The unusual pollination system and complex evolution of the genus is probably an important reason for confused taxonomy. Modern estimation of the species richness varies from 9 macrospecies based on the results of molecular analysis (Bateman et al., 2018) to 354 microspecies based on minute morphological differences (Delforge, 2016). Taxonomic differences can arise because of conceptual differences between "lumpers" and "splitters" and can cause extensive debates over species richness within the genus (Vereecken et al., 2011; Bateman et al., 2011; Véla et al., 2015). We believe the genus has somewhat more than 19 species recognized by H. Æ. Pedersen and N. Faurholdt (2007) but considerably less than 354 species recognized by P. Delforge (2016). In our opinion, most of the 28 species groups listed in P. Delforge (2016) could be treated at species rank (with several subspecies within the majority of them).

Species of the genus Ophrys are distributed from Scandinavia to North Africa and from the Canary Islands and Ireland to Iran and Turkmenistan (Pavlenko et al., 2015). Three species are traditionally recognized in the Crimea (Wulff, 1930; Yena, 2012; Fateryga, Kreutz, 2014): O. apifera, O. mammosa Desf., and O. oestrifera M. Bieb. In the Caucasus, three similar morphotypes occur, but due to higher morphological variability, the taxonomical accounts for the Caucasus are considerably more diverse. For example, A. S. Zernov (2006) reported the same three species (O. apifera, O. mammosa, and $O$. oestrifera); however, L. V. Averyanov (2006) added $O$. caucasica Woronow ex Grossheim, O. caucasica subsp. cyclocheila Aver., and O. oestrifera subsp. bremifera (Steven) K. Richt. In addition, P. Delforge (2006) accepted another taxon, O. abchasica (Kümpel) P. Delforge, as a separate species; at the same time, he treated $O$. oestrifera subsp. bremifera as the hybrid between $O$. abchasica and O. apifera (Delforge, 2016). The main problem is that neither of these points of view coincides with modern taxonomic databases, such as "World Checklist of Selected Plant Families" (Govaerts et al., 20052018). For example, those who accept broad taxonomic concept in the genus Ophrys ("lumpers") do not accept $O$. oestrifera as a species but treat it as the synonym of $O$. apifera (Govaerts et al., 20052018). Therefore, $O$. oestrifera is often merged into O. apifera, even in some Russian databases (Seregin, 2018). Conversely, "World Checklist of Selected Plant Families" (Govaerts et al., 2005-2018) accepts two subspecies of $O$. scolopax Cav. instead of O. oestrifera: O. scolopax subsp. scolopax and O. scolopax subsp. cornuta (Steven) E. G. Camus, the former with $O$. oestrifera subsp. bremifera and $O$. abchasica as the synonyms. Furthermore, those who accept narrow taxonomic concept in the genus Ophrys ("splitters") treat O. mammosa, O. caucasica, and O. cyclocheila (Aver.) P. Delforge as three separate species (Delforge, 2006, 2016), while "lumpers" merge all of them into one taxon named 
O. sphegodes subsp. mammosa (Desf.) Soó ex E. Nelson (Govaerts et al., 2005-2018). These taxonomical controversies have led to the problem of the East European Ophrys taxa being incorporated into the context of the taxonomy developed for West and Central European plants. The main subject of the current article is the taxonomic revision of the Crimean and North Caucasian Ophrys species as an attempt to solve this problem.

Our study was conducted with traditional taxonomic methods. All protologues of the Ophrys taxa described from the Crimea and the Caucasus, as well as additional relevant references, were studied. The types of most taxa were examined. Additional preserved specimens were studied in several herbaria (primarily LE, MW, and YALT). Living plants were observed in the Crimea and the Krasnodar Territory in 2016-2017. We used the morphological method and examined the main characters important to reproductive isolation of Ophrys taxa: flower shape and size. To create a compromise between taxonomic concepts of "lumpers" and "splitters", we accepted the following principles. First, we assumed that a subspecies is a population (or several populations) of the species with morphological differences recognized by taxonomists (Mayr, 1974). This assumption means that two subspecies cannot co-occur in the same place. At the same time, the assumption does not mean that any morphological difference between allopatric populations is the reason to recognize one of them as a separate subspecies. Many such differences are unstable and associated with ecological conditions (Mayr, 1974). Second, we accept biological species as evolutionary independent entities (Rasnitsyn, 1975). This approach means that sympatric biparental species show reproductive independence in spite of occasional cases of interspecific hybridization. Finally, we assume that closely related sympatric species must have either significantly different floral morphology that cause the restriction of their pollinator ranges or, more commonly, different phenology and/or habitat preferences (Vakhrameeva, Dlussky, 1994). This finding means that two closely related species with flowers of the same size and similar shape cannot co-occur in the same place if they have the same flowering time. Regarding the above considerations, we developed a revised species account of the genus Ophrys in the Crimea and the North Caucasus.

\section{Species account}

Ophrys apifera Huds. (Fig. 1A-B)

Ophrys apifera Huds. 1762, Fl. Angl. (Hudson): 340. $\equiv$ Orchis apifera (Huds.) Salisb. 1796, Pro- dr. Stirp. Chap. Allerton: 7. $\equiv$ Arachnites apifera (Huds.) Hoffm. 1804, Deutschl. Fl., Jahrgang 4 (Hoffm.), ed. 2, 1(2): 180.

Lectotypus (Baumann et al., 2002, J. Eur. Orch. 34(1): 179): Illustration in Gerard, 1633, Herball, ed. 2: 212, Fig. 3 [based on a specimen collected in Belgium, Flemish Brabant, probably in the vicinity of Leuven].

Distribution: Most of Western, Southern, and Eastern Europe (eastwards to Ukraine), Crimea, Caucasus, North Africa, and Western Asia (except south of the Arabian Peninsula) (Nevski, 1935; Smolyaninova, 1976; Renz, Taubenheim, 1984; Averyanov, 2006; Delforge, 2006; Danylyk, Borsukevych, 2011; Kreutz, Spencer, 2011).

Notes: Ophrys apifera is the only self-pollinating species of the genus. In the Crimea and the North Caucasus, the species is widespread but is more rare than other Ophrys species.

The name $O$. apifera is considered synonymous with $O$. oestrifera in some modern treatments (Govaerts et al., 2005-2018; Devey et al., 2008) which could be considered to be a mistake (see further discussions under $O$. oestrifera). In fact, both taxa belong to different "larger" clades (cf. Bateman et al., 2018) within the genus: apifera group and fuciflora group, respectively.

Ophrys mammosa Desf. subsp. mammosa (Fig. $1 \mathrm{C}-\mathrm{D})$

Ophrys mammosa Desf. 1807, Ann. Mus. Hist. Nat. 10: 222. $\equiv$ Ophrys aranifera var. mammosa (Desf.) Rchb. f. in Rchb. 1851, Icon. Fl. Germ. Helv. (H. G. L. Reichenbach), 13/14: 89. इOphrys aranifera subsp. mammosa (Desf.) Soó, 1926, Notizbl. Bot. Gart. Berlin-Dahlem, 9: 907. $\equiv$ Ophrys sphegodes subsp. mammosa (Desf.) Soó ex E. Nelson, 1962, Gestaltw. Artb. Orchid. Eur. Mittelmeerl.: 184.

Holotypus: Unpublished illustration by C. Aubriet, "Vélins du Museum", T. XIV, No. 11, kept in the Central Library of the National Museum of Natural History, Paris [based on a specimen collected in Turkey, Anatolia, probably between Smyrna (currently Izmir) and Kuşadası].

Epitypus (Devillers et Devillers-Terschuren, 2013, Naturalistes Belges, 94(Orchid. 26): 277): Turkey: "Turcia: Prov. Izmir (B1). 30 III 1980. J. Renz, G. Taubenheim 12589” (RENZ 12589!).

= Ophrys aranifera var. taurica Aggeenko, 1886 (publ. 1887), Bot. Zap. 1: 291-292. 三Ophrys aranifera subsp. taurica (Aggeenko) K. Richt. 1890, Pl. Eur. 1: 263. $\equiv$ Ophrys aranifera f. taurica (Aggeenko) Soó, 1928, Bot. Arch. 23: 28. 三Ophrys sphe- 
godes subsp. taurica (Aggeenko) Soó, 1959, Acta Bot. Acad. Sci. Hung. 5(3/4): 444. $\equiv$ Ophrys mammosa subsp. taurica (Aggeenko) Soó, 1974, Feddes Repert. 85(7/8): 446.

Lectotypus (Averyanov, 1994, Bot. Zhurn. (St. Petersburg), 79(10): 124): Russia (Crimea): “Tauria. Mischor. IV. V. N. Aggeenko s. n.” (LE!).

= Ophrys caucasica subsp. cyclocheila Aver., 1994, Bot. Zhurn. (St. Petersburg), 79(10): 124, syn. nov. $\equiv$ Ophrys mammosa subsp. cyclocheila (Aver.) B. Baumann, H. Baumann, R. Lorenz et Ruedi Peter, 2003, J. Eur. Orch. 35(1): 172. $\equiv$ Ophrys cyclocheila (Aver.) P. Delforge, 2004, Naturalistes Belges, 85(Orchid. 17): 252.

Holotypus: Azerbaijan: "Бакин. г., Геокчай у. Сел. Касин-беглы, ст. Кара-сахкал [Baku prov., Geokchay uyezd. Vill. Kasin-begly, st. Kara-sakhkal]. 9 IV 1906. A. Shelkovnikov s. n.” (LE!).

Distribution: Southern Balkans, Cyprus, Crimea, Caucasus, Anatolia, and west of the Arabian Peninsula (Renz, Taubenheim, 1984; Kreutz, 2004b; Averyanov, 2006; Delforge, 2006).

Notes: Broader taxonomic concept, $O$. mammosa is subsumed into $O$. sphegodes Mill. (e. g., Govaerts et al., 2005-2018), which is disputable. We accept the traditional point of view and treat $O$. mammosa and $O$. sphegodes as separate species, although they are allopatric species with several subspecies within each of them (e. g., Kreutz, 2004a). These two species are not closely related in some cladograms (e. g., Breitkopf et al., 2015).

Within the North Caucasus, O. mammosa subsp. mammosa is undoubtedly present only in the Republic of Dagestan. Reports of $O$. mammosa from south of Krasnodar Territory and Abkhazia (e. g., Averyanov, 2006) obviously refer to O. mammosa subsp. caucasica (Woronow ex Grossh.) Soó (see below).

Ophrys mammosa subsp. caucasica (Woronow ex Grossh.) Soó (Fig. 1E-F)

Ophrys caucasica Woronow ex Grossheim, 1928, Fl. Kavkaza [Grossheim], 1: 261. EOphrys sphegodes subsp. caucasica (Woronow ex Grossh.) Soó, 1959, Acta Bot. Acad. Sci. Hung. 5(3/4): 444. $\equiv$ Ophrys mammosa subsp. caucasica (Woronow ex Grossh.) Soó, 1973, Acta Bot. Acad. Sci. Hung. 18(3/4): 383 .

Lectotypus (Averyanov, 1994, Bot. Zhurn. (St. Petersburg), 79(10): 123): Abkhazia: "In pratis prope Jurjewskoje (Tzebelda). 2 V 1904. G. Woronow 196" (LE!).

Distribution: Caucasus and adjacent eastern territories of Anatolia (Nevski, 1935; Kreutz, 2003; Averyanov, 2006; Delforge, 2006).
Notes: This subspecies is well-distinguished morphologically from the nominative one in having smaller flowers, lip deeply divided on three lobes (versus entire lip), and unicoloured (usually greenish or sometimes pinkish) lateral sepals (versus sepals with green upper part and reddish lower one). Differences among subspecies are not large, while at the same time, the differences do not appear to be highly stable. Thus, some specimens of $O$. mammosa subsp. caucasica have lip similar in structure to O. mammosa subsp. mammosa (but at the same time, they have smaller flowers and unicoloured lateral sepals). Therefore, we consider that $O$. mammosa subsp. caucasica does not merit species rank.

Within the North Caucasus, O. mammosa subsp. caucasica occurs primarily along the coast of the Black Sea (in the Krasnodar Territory and Abkhazia). This subspecies has allopatric distribution with O. mammosa subsp. mammosa. Some specimens of O. mammosa subsp. caucasica have characters somewhat intermediate between $O$. mammosa s. 1. and $O$. oestrifera (e. g., pinkish sepals, weakly developed but clear pubescence of the petals, and yellowish-edged speculum). This observation could mean that $O$. mammosa subsp. caucasica may have a partially introgressive origin.

Those who accept the broadest species concept in Ophrys, may treat two subspecies of O. mammo$s a$ as $O$. sphegodes subsp. mammosa and $O$. sphegodes subsp. caucasica, respectively.

Ophrys oestrifera M. Bieb. (Fig. 1G-J)

Ophrys oestrifera M. Bieb. 1808, Fl. Taur.-Caucas. 2: 369. $\equiv$ Orchis oestrifera (M. Bieb.) M. Bieb. 1819, Fl. Taur.-Caucas. 3: 605. $\equiv$ Ophrys scolopax var. oestrifera (M. Bieb.) Rchb. f. in Rchb. 1851, Icon. Fl. Germ. Helv. (H. G. L. Reichenbach), 13/14: 99. $\equiv$ Ophrys scolopax subsp. oestrifera (M. Bieb.) Soó, 1970 (publ. 1971), Acta Bot. Acad. Sci. Hung. 16(3/4): 386.

Lectotypus (Averyanov, 1994, Bot. Zhurn. (St. Petersburg), 79(10): 124): Russia (Crimea): "Taur. mer. 1807. Ch. Steven s. n." (LE!).

$=$ Ophrys bremifera Steven in M. Bieb. 1808, Fl. Taur.-Caucas. 2: 370, syn. nov. $\equiv$ Ophrys oestrifera subsp. bremifera (Steven) K. Richt. 1890, Pl. Eur. 1: 264. $\equiv$ Ophrys oestrifera f. bremifera (Steven) Soó, 1928, Bot. Arch. 23: 32. $\equiv$ Ophrys scolopax subsp. bremifera (Steven) Biel, 1999, Ber. Arbeitskreis. Heimische Orchid. 16(1): 54.

Lectotypus (Averyanov, 1994, Bot. Zhurn. (St. Petersburg), 79(10): 124): Georgia: "Ex Iberia. 1808. Ch. Steven s. n.” (LE!). 
= Ophrys cornuta Steven in M. Bieb. 1808, Fl. Taur.-Caucas. 2: 370. $\equiv$ Ophrys bicornis var. cornuta (Steven) Nyman, 1882, Consp. Fl. Eur.: 698. $\equiv$ Ophrys oestrifera subsp. cornuta (Steven) K. Richt. 1890, Pl. Eur. 1: 264. $\equiv$ Ophrys arachnites var. cornuta (Steven) Fiori et Paol. in Fiori., Bég. et Paol. 1896, Fl. Italia [Fiori, Béguinot et Paoletti], 1: 236. $\equiv$ Ophrys scolopax subsp. cornuta (Steven) E. G. Camus in E. G. Camus, Bergon et A. Camus, 1908, Monogr. Orchid.: 270. $\equiv$ Ophrys holoserica subsp. cornuta (Steven) H. Sund. 1975, Taxon, 24(5/6): 625 . $\equiv$ Ophrys fuciflora subsp. cornuta (Steven) H. Sund. 1980, Europ. Medit. Orchid. ed. 3: 39.

Type locality: Georgia: "Cachetiâ inferiore (Kisich)" (lectotypus is not designated but mentioned by Renz, Taubenheim, 1984 as if they have seen it in $\mathrm{H})$.

= Ophrys oestrifera subsp. abchasica Kümpel, 1988, Ber. Arbeitskreis. Heimische Orchid. 5(1/2): 25 , syn. nov. $\equiv$ Ophrys abchasica (Kümpel) P. Delforge in P. Delforge, Devillers-Tersch. et Devillers, 1991, Naturalistes Belges, 72(3): 100.

Holotypus: Russia (Krasnodar Territory): "Sotschi, Msymta-Tal. 17 V 1979. H. Kümpel s. n.” (JE 00014373!).

Distribution: Balkans, Crimea, Caucasus, and Western Asia (except south of the Arabian Peninsula) (Nevski, 1935; Smolyaninova, 1976; Renz, Taubenheim, 1984; Averyanov, 2006; Delforge, 2006; Kreutz, Spencer, 2011).

Notes: Those who accept species of Ophrys in the broadest sense may merge $O$. oestrifera into $O$. scolopax, while another opinion is to treat it as Ophrys scolopax subsp. oestrifera. This approach is similar to the case of $O$. sphegodes - O. mammosa (see above). However, the recent phylogenetic analysis (Bateman et al., 2018) showed $O$. oestrifera and O. scolopax are not so closely related.

Ophrys oestrifera is the most common Ophrys species within the Crimea and the Caucasus. This name was traditionally accepted by numerous authors (Wulff, 1930; Nevski, 1935; Smolyaninova, 1976; Baumann, Künkele, 1982; Renz, Taubenheim, 1984; Averyanov, 2006; Yena, 2012). However, recently, this approach was questioned (Govaerts et al., 2005-2018) by reducing it to the synonymy of $O$. apifera, with the name $O$. scolopax subsp. cornuta being used instead of $O$. oestrifera. This last point of view we consider incorrect, as it is not supported by the type material of $O$. oestrifera and is probably derived from the analysis of the protologue. The problem is that the protologue of $O$. oestrifera (Marschall von Bieberstein, 1808) had been based on the data on Ophrys systematics provided by $\mathrm{Ch}$. von Steven, who understood taxa in a different way. Steven independently explained his point of view in detail a year later (Steven, 1809), where he accepted $O$. oestrifera and described two more species, $O$. cornuta and $O$. bremifera, providing them with schematic sketches of the flowers. Thus, if we study the sketches, it is not Steven's drawing of $O$. oestrifera flower but rather the $O$. cornuta flower (Steven, 1809: Fig. 3), which corresponds to F. A. Marschall von Bieberstein's type specimen of $O$. oestrifera. Steven's drawing of $O$. oestrifera from Georgia (Steven, 1809: Fig. 4) shows characters intermediate between $O$. apifera (long and entire appendage of the lip) and O. oestrifera (short and straight appendage of the gynostemium) and may either depict some hybrid or represent an unsatisfactory mixture of the traits of various specimens within one flower. Steven also presented a drawing of what he had assumed to be a new species "closely related to O. oestrifera" (Steven, 1809: Fig. 5), and this last drawing depicts $O$. apifera, as it was already noticed by E. W. Wulff (1930). Steven's determinations of herbarium specimens are in line with this: both $O$. oestrifera and $O$. apifera, collected by him in the Crimea, are named "O. oestrifera". It should be noted that later Steven changed his point of view, which is evident from a detailed drawing of $O$. oestrifera (Steven, 1857: Fig. 2), which corresponds well to the type specimen of this species and to its modern understanding. By that time, he had "forgotten" about his $O$. cornuta and did not mention it in his publications (Wulff, 1930).

D. S. Devey et al. (2008) placed O. oestrifera within $O$. apifera according to their molecular analysis. However, it was later reported by R. M. Bateman et al. (2018) that a misidentified vegetative sample of $O$. apifera had represented " $O$. oestrifera" in the tree of D. S. Devey et al. (2008).

Ophrys oestrifera is variable across its distribution range within the Crimea and the Caucasus. The most deviated form is one from south of Krasnodar Territory, which was described by H. Kümpel (1988) as $O$. oestrifera subsp. abchasica and accepted as a full species by P. Delforge (Delforge et al., 1991). This form has a small and entire appendage of the lip (Fig. 1I-J), which is in opposition to the large and tridentate appendage in typical $O$. oestrifera (Fig. 1G-H), and its upper sepal is curved forward and covers the gynostemium. Furthermore, this subspecies has a later flowering time from May to June, whereas flowering from April to May is characteristic for typical $O$. oestrifera. However, in our opin- 
ion, these characters are not sufficient to recognize it as a separate taxon, because in the Caucasus, it has numerous intermediates with typical $O$. oestrifera (e. g., see images by E. A. Averyanova (2015) made from the environs of the type locality of $O$. oestrifera subsp. abchasica). We consider that both the flowering time and the curvature of the upper sepal may be associated with the ecology: plants from humid places (environs of Sochi or Abkhazia) flower later and have more curved upper sepal than plants growing in arid habitats (Crimea or north of Krasnodar Territory). The protologue of $O$. cornuta also corresponds to this entity. Unfortunately, we were unable to discover type specimen of $O$. cornuta as it seems to be lost, although J. Renz and G. Taubenheim (1984) reported as if they have seen it in $\mathrm{H}$.

Another form of $O$. oestrifera was described by Ch. von Steven (1809) as O. bremifera. Modern botanists usually treat it as a subspecies (Baumann, Künkele, 1982; Akhalkatsi et al., 2003; Averyanov, 2006), attributing this name to the specimens of $O$. oestrifera, which has short horn-like lateral appendages of the lip. According to our observations, the length of these appendages can vary within a single population; therefore, their length does not have taxonomic importance. Specimens with short appendages occur not only in the Caucasus but in the Crimea, as well (Hahn, 2012: Fig. 40). It should be noted that the drawing of $O$. bremifera in the protologue (Steven, 1809: Fig. 2) exhibits a notably long appendage of the gynostemium as in $O$. apifera. This observation may be attributable to the low quality of the sketches in this publication, as far as the type specimen has appendage of the gynostemium, which is typical for $O$. oestrifera. $\mathrm{P}$. Delforge (2016) treated $O$. bremifera as a hybrid between $O$. abchasica and $O$. apifera.

According to "World Checklist of Selected Plant Families" (Govaerts et al., 2005-2018), both $O$. bremifera and $O$. oestrifera subsp. abchasica are synonyms of $O$. scolopax subsp. scolopax, which is distributed in the West Mediterranean (Delforge, 2006). This classification is clearly a mistake.

Ophrys $\times$ vallis-costae Kümpel (Fig. $1 \mathrm{~K}-\mathrm{L}$ )

Ophrys $\times$ vallis-costae Kümpel, 1988, Ber. Arbeitskreis. Heimische Orchid. 5(1/2): 27 (described as hybrid of "Ophrys apifera Huds. $\times O$. oestrifera subsp. abchasica Kümpel”).

Holotypus: Russia (Krasnodar Territory): "Sotschi, Kosta-Tal. 2 VI 1982. H. Kümpel s. n.” (JE 00014374 !).

$=$ Ophrys $\times$ skopelii nothosubsp. markiana B. Baumann, H. Baumann, R. Lorenz et Ruedi Pe- ter, 2003, J. Eur. Orch. 35(1): 186 (hybrid of Ophrys apifera Huds. $\times$ O. oestrifera subsp. bremifera (Steven) K. Richt.), syn. nov.

Holotypus: Azerbaijan: "Samaxi, Sirvalizada, 780 m, pratum. 1 VI 1997. B. Baumann, H. Baumann s. n." (STU).

Specimens examined: Russia: "Crimea, vicinity of Feodosiya, Mt Tepeoba, row-spacing of plantation of Pinus nigra subsp. pallasiana and Pistacia vera, $45^{\circ} 00^{\prime} 45^{\prime \prime} \mathrm{N}, 35^{\circ} 23^{\prime} 40^{\prime \prime} \mathrm{E} .17 \mathrm{~V} 2016$. V. V. Fateryga, A. V. Fateryga s. n." (LE and PHEO).

Distribution: The hybrid is known by three isolated records from the Krasnodar Territory of Russia (Kümpel, 1988), Azerbaijan (Baumann et al., 2003), and the Crimea (new record).

Notes: Ophrys $\times$ skopelii Renz was described as the hybrid between $O$. apifera and $O$. cornuta (Renz, 1928). The described specimen, however, was later attributed to a hybrid of $O$. fuciflora (F. W. Schmidt) Moench and O. scolopax subsp. scolopax, O. × vetula Risso (RENZ 277, URL: https:// orchid.unibas.ch/index.php/en/database-search/ advanced-search?SearchResultID=277). Thus, the name $O$. $\times$ skopelii is incorrect to use for hybrids of $O$. apifera and $O$. oestrifera. Ophrys $\times$ vallis-costae was described as the hybrid between $O$. apifera and $O$. oestrifera subsp. abchasica (Kümpel, 1988). The latter species, in our opinion, is a synonym of $O$. oestrifera $\mathrm{s}$. str. Thus, the name $O . \times$ vallis-costae can be used for all hybrids between $O$. apifera and $O$. oestrifera (including our record of such hybrid in the Crimea).

\section{Key to species and subspecies of the genus Ophrys in the Crimea and the North Caucasus}

1. Petals about two times shorter than sepals or some longer, hairless or indistinctly pubescent; sepals usually \pm green .......................................... 2

+ Petals three or more times shorter than sepals, distinctly pubescent; sepals usually pink ............ 3

2. Lateral sepals unicoloured, green or rarely pinkish; lip \pm trilobed

O. mammosa subsp. caucasica

+ Lateral sepals have green upper parts and reddish lower ones; lip \pm entire

O. mammosa subsp. mammosa

3. Appendage of lip turned upwards; appendage of gynostemium straight; lateral lobes of lip with acute "horns" ..................................... O. oestrifera

+ Appendage of lip turned downwards; appendage of gynostemium strongly tortuous; lateral lobes of lip with obtuse protuberances ........... O. apifera 


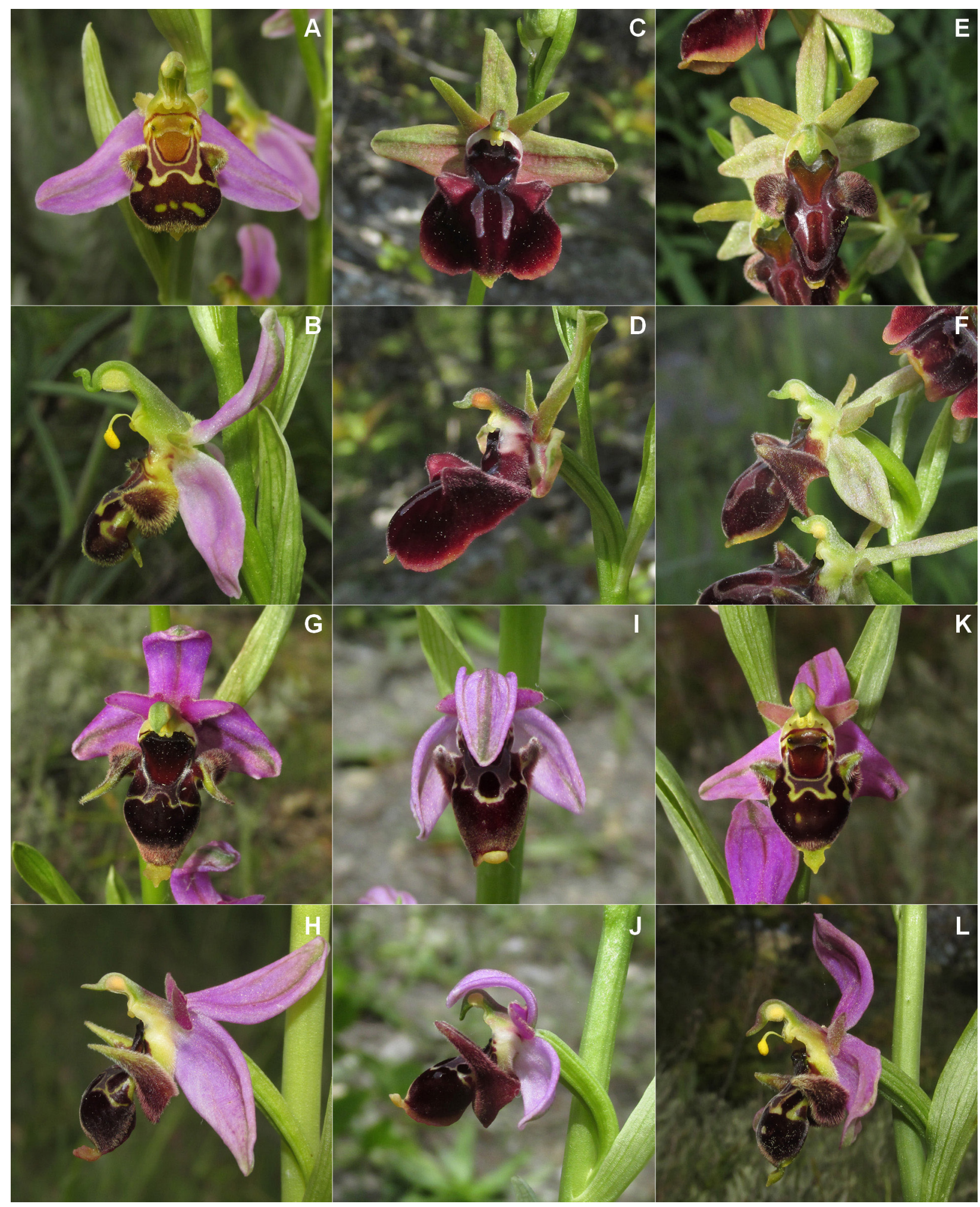

Fig. 1. Flowers of Ophrys spp. from the Crimea and the North Caucasus: A-B - O. apifera Huds. (Crimea, vicinity of Feodosiya, Mt Tepeoba); C-D - O. mammosa Desf. subsp. mammosa (Crimea, Sevastopol, vicinity of Ternovka); E-F O. mammosa subsp. caucasica (Woronow ex Grossh.) Soó (Krasnodar Territory, Novorossiysk); G-J - O. oestrifera M. Bieb. (G-H - Crimea, vicinity of Feodosiya, Mt Tepeoba; I-J - Krasnodar Territory, Sochi, valley of riv. Msymta, vicinity of Monastyr'); K-L - O. × vallis-costae Kümpel (Crimea, vicinity of Feodosiya, Mt Tepeoba). Photos by A. V. Fateryga. 


\section{Conclusions}

Five taxa in the genus Ophrys are recognized in the Crimea and the North Caucasus: O. apifera Huds., O. mammosa Desf. subsp. mammosa, O. mammosa subsp. caucasica (Woronow ex Grossh.) Soó, O. oestrifera M. Bieb., and $O . \times$ vallis-costae Kümpel $(O$. apifera $\times O$. oestrifera $)$. The last of these taxa is not included in the presented key above; this hybrid can be recognized by the characters intermediate between parental species.

\section{Acknowledgements}

The study by Petr Efimov was carried out within the framework of the institutional research project (no. AAAA-A18-118030590100-0) of the V. L. Komarov Botanical Institute of the Russian Academy of Sciences.

We thank Karel Kreutz (Naturalis Biodiversity Center, Leiden, the Netherlands) for providing several references. Special thanks to Anton Popovich (Novorossiysk, Russia) and Elena Averyanova (Sochi, Russia) for their help with field observations of Ophrys spp. in Krasnodar Territory in 2017.

\section{REFERENCES}

Akhalkatsi M., Kimeridze M., Künkele S., Lorenz R., Mosulishvili M. 2003. Diversity and conservation of Georgian orchids. CGS Ltd., Tbilisi, 40 pp.

Averyanov L. V. 2006. Orchidaceae Juss. In: Konspekt flory Kavkaza [Caucasian flora conspectus]. Vol. 2. Ed. A. L. Tahktadjan. St. Petersburg University Press, St. Petersburg, 84-101 pp. [In Russian]. (Аверьянов В. Л. Orchidaceae Juss. // Конспект флоры Кавказа. Т. 2. Под ред. А. Л. Тахтаджяна. СПб.: Изд-во Санкт-Петербургского ун-та, 2006. C. 84-101).

Averyanova E. A. 2015. Features of biology and ecology of Ophrys oestrifera Bieb. (Orchidaceae) in Sochi Black Sea coast. In: Problems of botany of South Siberia and Mongolia: Proceedings of the $14^{\text {th }}$ International Scientific and Practical Conference (Barnaul, 25-29 May 2015). Altai State University, Barnaul, 240-249 pp. [In Russian]. (Аверьянова $\boldsymbol{E}$. A. Особенности биологии и экологии Ophrys oestrifera Bieb. (Orchidaceae) в Сочинском Причерноморье // Проблемы ботаники Южной Сибири и Монголии: Сб. науч. ст. по материалам XIV междунар. науч.-практ. конф. (Барнаул, 25-29 мая 2015 г.). Барнаул: Изд-во АлтГУ, 2015. С. 240-249).

Ayasse M., Gögler J., Stökl J. 2010. Pollinator-driven speciation in sexually deceptive orchids of the genus $O p h$ rys. In: Evolution in action. Ed. M. Glaubrecht. Springer, Berlin, 101-118 pp. DOI: 10.1007/978-3-642-12425-9_6

Bateman R. M., Bradshaw E., Devey D. S., Glover B. J., Malmgren S., Sramkó G., Thomas M. M., Rudall P. J. 2011. Species arguments: clarifying competing concepts of species delimitation in the pseudo-copulatory orchid genus Ophrys. Bot. J. Linn. Soc. 165(4): 336-347. DOI: 10.1111/j.1095-8339.2011.01121.x

Bateman R. M., Sramkó G., Paun O. 2018. Integrating restriction site-associated DNA sequencing (RAD-seq) with morphological cladistic analysis clarifies evolutionary relationships among major species groups of bee orchids. Ann. Bot. (Oxford). DOI: 10.1093/aob/mcx129

Baumann B., Baumann H., Lorenz R., Peter R. 2003. Beitrage zur Orchideenflora des östlichen Transkaukasus und Talysch (Aserbaidschan). J. Eur. Orch. 35(1): 163-231.

Baumann H., Künkele S. 1982. Beiträge zur Taxonomie von Ophrys oestrifera M.-Bieb. und O. scolopax Cav. Mitteilungsbl. Arbeitskreis Heimische Orchid. Baden-Württemberg 14(2): 204-238.

Bradshaw E., Rudall P., Devey D. S., Thomas M. M., Glover B., Bateman R. M. 2010. Comparative labellum micromorphology of the sexually deceptive temperate orchid genus Ophrys: diverse epidermal cell types and multiple origins of structural colour. Bot. J. Linn. Soc. 162(3): 504-540. DOI: 10.1111/j.1095-8339.2010.01033.x

Breitkopf H., Onstein R. E., Cafasso D., Schlüter P. M., Cozzolino S. 2015. Multiple shifts to different pollinators fuelled rapid diversification in sexually deceptive Ophrys orchids. New Phytol. 207(2): 377-389. DOI: 10.1111/ nph.13219

Brown R. 1833. On the organs and mode of fecundation in Orchideae and Asclepiaeae. Trans. Linn. Soc. London 16(3): 685-745.

Danylyk I. M., Borsukevych L. M. 2011. A new find of Ophrys apifera Huds. (Orchidaceae) in Ukraine. Ukr. Bot. Zhurn. 68(1): 58-63 [In Ukrainian]. (Данилик I. М., Борсукевич Л. М. Нове місцезнаходження Ophrys apifera Huds. (Orchidaceae) в Україні // Укр. бот. журн., 2011. Т. 68, № 1. С. 58-63).

Delforge P. 2006. Orchids of Europe, North Africa and the Middle East, $3^{\text {rd }}$ ed. A\&C Black Publishers Ltd., London, $640 \mathrm{pp}$.

Delforge P. 2016. Orchidées d'Europe, d'Afrique du Nord et du Proche-Orient, 4e éd. Delachaux \& Nistlé, Paris, $544 \mathrm{pp}$.

Delforge P., Devillers-Terschuren J., Devillers $\boldsymbol{P}$. 1991. Contributions taxonomiques et nomenclaturales aux Orchidées d'Europe (Orchidaceae). Naturalistes Belges 72(3): 99-101. 
Devey D. S., Bateman R. M., Fay M. F., Hawkins J. A. 2008. Friends or relatives? Phylogenetics and species delimitation in the controversial European orchid genus Ophrys. Ann. Bot. (Oxford) 101(3): 385-402. DOI: 10.1093/ $\mathrm{aob} / \mathrm{mcm} 299$

Fateryga A. V., Kreutz C. A. J. 2014. Checklist of the orchids of the Crimea (Orchidaceae). J. Eur. Orch. 46(2): 407-436.

Govaerts R., Bernet P., Kratochvil K., Gerlach G., Carr G., Alrich P., Pridgeon A. M., Pfahl J., Campacci M. A., Holland Baptista D., Tigges H., Shaw J., Cribb P., George A., Kreutz K., Wood J. 2005-2018. World Checklist of Orchidaceae. Royal Botanic Gardens, Kew. URL: http://apps.kew.org/wcsp/ (Accessed 10 January 2018).

Hahn W. 2012. Auf den Spuren von Christian von Steven: Orchideen- und Bestäuberuntersuchungen im Krimgebirge 2011 und 2012. Ber. Arbeitskreis. Heimische Orchid. 29(2): 5-63.

Hollingsworth P. M., Squirrell J., Hollingsworth M. L., Richards A. J., Bateman R. M. 2006. Taxonomic complexity, conservation and recurrent origins of self-pollination in Epipactis (Orchidaceae). In: Current taxonomic research on the British and European flora. Eds. J. Bailey, R. G. Ellis. BSBI, London, 27-44 pp.

Kreutz C. A. J. 2003. Feldfuhrer der turkischen Orchideen. Eigenverlag, Landgraaf, 204 pp.

Kreutz C. A. J. 2004a. Kompendium der europäischen Orchideen / Catalogue of European Orchids. Kreutz Publishers, Landgraaf, 239 pp.

Kreutz C. A. J. 2004b. Die Orchideen von Zypern / The orchids of Cyprus. Eigenverlag, Landgraaf, 416 pp.

Kreutz C. A. J., Spencer J. 2011. In the footsteps of Renz: Orchids in Iran. J. Hardy Orch. Soc. 8(1): 12-24.

Kullenberg B. 1961. Studies in Ophrys pollination. Almqvist \& Wiksells, Uppsala, 340 pp. +51 pl.

Kümpel H. 1988. Über neue Orchideen aus dem Gebiet des Schwarzmeer-Kaukasus. Ber. Arbeitskreis. Heimische Orchid. 5(1/2): 24-37.

Mant J., Peakall R., Schiestl F. P. 2005. Does selection on floral odor promote differentiation among populations and species of the sexually deceptive orchid genus Ophrys? Evolution 59(7): 1449-1463. DOI: 10.1111/j.00143820.2005.tb01795.x

Marschall von Bieberstein F. A. 1808. Flora taurico-caucasica exhibens stirpes phaenogamas, in Chersoneso Taurica et regionibus caucasicis sponte crescentes. Vol. 1. Typis Academicis, Kharkov, vi + 429 pp. DOI: 10.5962/ bhl.title. 10825

Mayr E. 1974. Populyacii, vigy i evolyuciya [Populations, species, and evolution]. Mir, Moscow, 460 pp. [In Russian]. (Майр Э. Популяции, виды и эволюция. М.: Мир, 1974. 460 с.).

Nevski S. A. 1935. Orchidaceae Lindl. In: Flora URSS [Flora of USSR]. Vol. 4. Ed. V. L. Komarov. Academy of Sciences of USSR Press, Leningrad, 589-730 pp. [In Russian]. (Невский С. A. Orchidaceae Lindl. // Флора CССР / Под ред. В. Л. Комарова. Л.: Изд-во АН СССР, 1935. Т. 4. С. 589-730).

Paulus H. F. 2006. Deceived males - Pollination biology of the Mediterranean orchid genus Ophrys (Orchidaceae). J. Eur. Orch. 38(2): 303-353.

Paulus H. F. 2007. Wie Insekten-Männchen von Orchideenblüten getäuscht werden - Bestäubungstricks und Evolution in der mediterranen Ragwurzgattung Ophrys. Denisia 20: 255-294.

Paulus H. F., Gack C. 1990. Pollinators as prepollinating isolation factors: Evolution and speciation in Ophrys (Orchidaceae). Israel J. Bot. 39(1): 43-79.

Pavlenko A. V., Kovalchuk A., Kreutz C. A. J. 2015. Rediscovery of Ophrys kopetdagensis K. Pop. et Neschat. in Southwestern Kopet Dag (Turkmenistan). J. Eur. Orch. 47(2/4): 457-465.

Pedersen H. AE., Faurholdt N. 2007. Ophrys: the bee orchids of Europe. Kew Publishing, London, 295 pp.

Rasnitsyn A. P. 1975. On species and speciation. In: Problemy evolyucii [Problems of evolution]. Vol. 4. Ed. N. N. Vorontsov. Nauka, Novosibirsk, 221-230 pp. [In Russian]. (Раснищын А. П. К вопросу о виде и видообразовании // Проблемы эволюции. Т. 4. Под ред. Н. Н. Воронцова. Новосибирск: Наука, 1975. С. 221-230).

Renz J. 1928. Zur Kenntnis der griechischen Orchideen. Repert. Spec. Nov. Regni Veg. 25: 225-270.

Renz.J., Taubenheim G. 1984. Orchidaceae. In: Flora of Turkey and the East Aegean Islands. Vol. 8. Ed. P. H. Davis. Edinburgh University Press, Edinburgh, 450-552 pp.

Seregin A. P. (ed.). 2018. Moscow University Herbarium (MW). Version 1.14. Lomonosov Moscow State University. Occurrence Dataset. URL: https://doi.org/10.15468/cpnhcc (Accessed via GBIF.org 10 January 2018).

Smolyaninova L. A. 1976. Orchidaceae Juss. In: Flora partis europaeae URSS [Flora of the European part of USSR]. Vol. 2. Eds. A. A. Fedorov, T. V. Egorova. Nauka, Leningrad, 10-59 pp. [In Russian]. (Смолянинова Л. А. Orchidaceae Juss. // Флора европейской части СССР. Т. 2. Под ред. А. А. Федорова и Т. В. Егоровой. Л.: Наука, 1976. C. 10-59).

Soliva M., Widmer A. 2003. Gene flow across species boundaries in sympatric, sexually deceptive Ophrys (Orchidaceae) species. Evolution 57(10): 2252-2261. DOI: 10.1111/j.0014-3820.2003.tb00237.x

Stebbins G. L., Ferlan L. 1956. Population variability, hybridization, and introgression in some species of Ophrys. Evolution 10(1): 32-46. DOI: 10.1111/j.1558-5646.1956.tb02827.x

Steven Ch. von. 1809. Decas plantarum, nondum descriptarum Iberiae et Rossiae meridionalis. Mém. Soc. Imp. Naturalistes Moscou 2: 173-183 + tab. XI. 
Steven Ch. von. 1857. Verzeichniss der auf der Taurischen Halbinsel wildwachsenden Pflanzen. Bull. Soc. Imp. Naturalistes Moscou 30, 3/4: 65-120 + tab. I.

Vakhrameeva M. G., Dlussky G. M. 1994. Flower morphology in three Campanula species as adaptation to caenotic surrounding. Zhurnal obshchey biologii [Journal of General biology] 55(3): 271-284 [In Russian]. (Baxpamee-

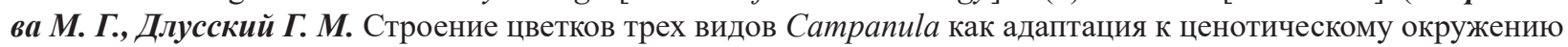
// Журн. общ. биол., 1994. Т. 55, № 3. С. 271-284).

Véla E., Rebbas K., Martin R., de Premorel G., Tison J.-M. 2015. Waiting for integrative taxonomy: Morphospecies as an operational proxy for the radiative and reticulate genus Ophrys L. (Orchidaceae)? Eur. J. Environm. Sci. 5(2): 153-157. DOI: 10.14712/23361964.2015.89

Vereecken N. J., Streinzer M., Ayasse M., Spaethe J., Paulus H. F., Stökl J., Cortis P., Schiestl F. P. 2011. Integrating past and present studies on Ophrys pollination - a comment on Bradshaw et al. Bot. J. Linn. Soc. 165(4): 329-335. DOI: 10.1111/j.1095-8339.2011.01112.x

Wulff E. W. 1930. Flora taurica [Flora of the Crimea]. Vol. 1, Fasc. 3. Nikitskiy Botanical Garden Press, Leningrad, 126 pp. [In Russian]. (Вульф E. В. Флора Крыма. Л.: Изд-во Никитского ботанического сада, 1930. Т. 1, вып. 3.126 с.).

Yena A. V. 2012. Prirorodnaya flora Krymskogo poluostrova [Spontaneous flora of the Crimean Peninsula]. N. Orianda, Simferopol, 232 pp. [In Russian]. (Ена A. В. Природная флора Крымского полуострова. Симферополь: Н. Оріанда, 2012. 232 с.).

Zernov A. S. 2006. Flora Severo-Zapadnogo Kavkaza [Flora of the North-Western Caucasus]. KMK Scientific Press Ltd., Moscow, 664 pp. [In Russian]. (Зернов $\boldsymbol{A}$. C. Флора Северо-Западного Кавказа. М.: Товарищество научных изданий КМК, 2006. 664 с.). 